\title{
Disonansi Kognitif Dalam Perilaku Konsumen Masyarakat Indonesia Terhadap Pembelian Produk Tanpa Logo Halal
}

\author{
Inke Nur Dewanti ${ }^{1^{*}}$, Irwansyah ${ }^{1}$ \\ ${ }^{1}$ Department of Communication Science, Universitas Indonesia \\ Jl. Margonda Raya, Pondok Cina, Kecamatan Beji, Kota Depok, Jawa Barat \\ E-mail: ${ }^{1}$ inke.nur01@ui.ac.id, ${ }^{1}$ irwansyah09@ui.ac.id
}

Received: Januari 2021; Accepted: April 2021; Published: Juni 2021

\begin{abstract}
Product without halal certification still become pro and contra in Indonesia's people whose mostly Muslim. These phenomena cause cognitive dissonance in some of Indonesia's people consumer behavior. This dissonance happens because there are values and culture that influence the consumer behavior on products without halal certification buying process. With those phenomena, this research examines the dissonance process of buying the products without halal certification. The research method used is the literature review, using secondary data from scientific journals, books, and media articles. The result of this research shows that some of Indonesia's Muslims being worried if there's no halal certification because there is some difference in value $\mathcal{E}$ culture with the product.
\end{abstract}

Keywords: Buying Process; Cognition Dissonance; Consumer Behaviour; Culture; Halal.

\begin{abstract}
Abstrak
Produk tanpa logo halal masih menjadi pro dan kontra bagi masyarakat Indonesia yang mayoritas dihuni oleh umat muslim. Hal ini membuat adanya disonansi kognisi di dalam perilaku konsumen di dalam beberapa masyarakat di Indonesia. Adanya nilai dan budaya yang dianut akan mempengaruhi dan menimbulkan disonansi pada perilaku konsumen dalam proses pembelian produk tanpa sertifikasi logo halal, sehingga penelitian ini mengkaji proses disonansi yang ada pada perilaku konsumen dalam membeli suatu produk tanpa adanya sertifikasi logo halal. Metode penelitian yang digunakan adalah studi pustaka, penelitian ini menggunakan data-data sekunder berupa jurnal ilmiah, buku, dan artikel di media massa. Hasil penelitian menunjukkan bahwa sebagian masyarakat Indonesia terutama masyarakat yang beragama muslim timbul adanya rasa khawatir dalam membeli suatu produk yang tidak ada sertifikasi logo halal, rasa khawatir ini ada karena adanya perbedaan nilai dan budaya yang tidak sesuai dengan produk yang ingin dibeli.
\end{abstract}

Kata Kunci: Disonansi Kognitif; Perilaku Konsumen; Proses Pembelian; Halal; Nilai; Budaya.

\section{PENDAHULUAN}

Indonesia merupakan negara mayoritas penduduk muslim. Tidak dipungkiri kebutuhan makanan dan minuman juga disesuaikan dengan kondisi dan nilai-nilai yang dianut oleh sebagian besar masyarakatnya. Halal sendiri merupakan istilah Islam tentang makanan berdasarkan ajaran Al Quran. Makanan itu sendiri dapat diklasifikasikan sebagai identitas dan budaya daerah. Seperti di Timur Tengah, ketika seseorang makan daging babi bisa dianggap non-muslim, begitu pula dengan di Indonesia karena halal menjadi suatu yang lumrah bagi masyarakat (Fithriana \& Annisa, 2017).

doi: https://doi.org/10.51544/jlmk.v5i1.1657

(C) 2021 Jurnal Lensa Mutiara Komunikasi. This is an open access article under the CC BY-SA license Website: http://e-journal.sari-mutiara.ac.id/index.php/JLMI/ 
Konsumen yang tinggal di kota atau wilayah multikultural kosmopolitan di seluruh dunia dapat mengkonsumsi produk halal secara teratur. Individu lainnya juga dapat mengonsumsi makanan halal saat mereka berkunjung baik untuk liburan atau bisnis. Saat ini banyak restoran dan rantai makanan cepat saji menawarkan produk halal untuk memuaskan segmen pasar Muslim. Untuk memenuhi segmen pasar ini, perusahaan-perusahaan umumnya melakukan standarisasi seluruh menu hingga halal. Akibatnya, tanpa disadari konsumen non-Muslim juga ikut mengkonsumsi produk halal (Wilkins, butt, shams, dan Perez 2017). Halal adalah frasa bahasa Arab untuk sesuatu yang diizinkan menurut hukum Islam (Riaz dan Chaudry, 2004).

Festinger, seorang psikolog sosial menggambarkan disonansi kognitif sebagai fenomena psikologis yang terjadi ketika ada ketidaksesuaian antara apa yang diyakini seseorang dan hasil yang mempertanyakan keyakinan seseorang (Festinger, 1957). Festinger juga menggambarkan disonansi kognitif sebagai keadaan yang muncul ketika seseorang menjadi bingung antara dua kognisi (pikiran), yang tidak dapat bersama dan memicu ketegangan. Saat orang tersebut percaya bahwa kedua pikiran itu benar, nantinya akan timbul ketegangan mental dalam pikirannya. Nantinya disonansinya akan memotivasi seseorang untuk menuju ke elemen yang tidak konsisten dan berujung mengurangi ketegangan psikologis (Festinger, 1957).

Berkaitan dengan standarisasi suatu produk seperti halal. Selama berabad-abad disonansi dalam perilaku konsumen telah membentuk imajinasi para pemegang pasar. Sejak munculnya perilaku konsumen, studi ekstensif menjadi kebutuhan untuk strategi pemasaran, sebuah studi yang dianggap rinci dan komprehensif serta aspeknya menjadi kebutuhan bagi keberhasilan suatu organisasi. Itulah sebabnya mengapa konsep disonansi kognitif dan pengaruhnya terhadap perilaku konsumen sering menjadi bagian dari berbagai studi penelitian terkait. Bahkan hal ini sering disebut sebagai salah satu teori psikologis sosial (Aronson, 1969).

Pada tahun 2017 muslim global mencapai 1,8 miliar orang dan diperkirakan akan terus berkembang. Pada tahun tersebut, industri halal berhasil meraup keuntungan lebih dari 2.107 miliar dolar per tahun (Standard \& Reuters, 2018). Makanan halal adalah bisnis yang menguntungkan di negara-negara dengan penduduk muslim. Diketahui, pendapatan dari sektor halal mengalami peningkatan karena banyaknya permintaan terutama makanan dan minuman (Ahmad, Abaidah, \& Yahya, 2013). Menurut Jurnal Aiedah Abdul Khalek di Malaysia, sikap konsumen terhadap makanan halal sangat erat kaitannya dengan sertifikasi halal yang dikeluarkan oleh JAKIM. Logo halal mencerminkan bahwa makanan tersebut boleh dikonsumsi oleh umat islam dan menandakan jika gerai tersebut telah menjalankan pemeriksaan ketat sebelum disertifikasi (Khaleka, 2014).

Kini, logo sertifikasi halal merupakan tolak ukur konsumen muslim dan non muslim (Ghadikolaei, 2016). Di Indonesia LPPOM-MUI menjadi lembaga yang mengeluarkan sertifikasi halal. Diketahui per tahun 2018 LPPOM UI telah mengeluarkan 58.959 sertifikasi halal dari 655.725 total produk yang beredar di pasaran (LPPOM MUI, 2018). Hal ini dilakukan sebagai upaya atas jaminan kebersihan dan keamanan produk (Awan, Siddiquei, \& Haider, 2015).

Menurut penelitian Ahmad, Kadir, dan Saleluddin 2013, kesadaran halal adalah keadaan sadar seorang muslim yang memiliki ilmu syariah yang baik tentang apa itu halal, mengetahui prosesnya dan mengutamakan yang halal untuk dikonsumsi (Ahmad, Kadir, \& Saleluddin, 2013). Haram dalam bahasa Arab berarti dilarang atau melanggar hukum, khususnya bagi muslim. Adapun contohnya seperti alkohol dan produk babi (Jusmaliani \& Nasution, 2009). Pada awal tahun 2019 tersebar berita melalui Whatsapp mengenai pencabutan sertifikat halal pada restoran cepat saji McDonald, KFC, Dominos, dan Pizza Hut karena disinyalir mayonaise yang digunakan mengandung babi (makanan non halal/haram bagi muslim) (Kominfo.go.id, 
2019). Hal ini kemudian menjadi pergolakan batin para pembeli/penikmat makanan cepat saji tersebut karena apa yang mereka konsumsi tidak sesuai dengan ketentuan yang selalu mereka yakini. Berdasarkan teori disonansi kognitif, setelah pembelian dilakukan, pikiran manusia mulai menilai pro dan kontra dari transaksi pembelian yang dilakukan. Aktivitas ini kemudian menimbulkan pemikiran yang bertentangan dari si pembeli. Aspek positif dari pilihan yang dilupakan dan aspek negatif dari keputusan yang dibuat menciptakan ketegangan yang meningkat dalam pikiran manusia dan membuat pembeli memikirkan kembali keputusan yang dibuat, catat Kassarjian dan Cohen (1965). Hingga akhirnya pada Oktober 2020 berdasarkan proses audit LPPOM MUI (Lembaga Pengkajian Pangan Obat obatan dan Kosmetika Majelis Ulama Indonesia) mengeluarkan klarifikasi resmi melalui website jika isu tersebut merupakan isu yang ditujukan kepada restoran McDonald, KFC, Domino's Pizza, dan Pizza Hut di Amerika dan Afrika Selatan bukan di Indonesia (halalmui.org, 2020).

Tak hanya makanan, pada website halalmui.org juga muncul dibahas terkait bir $0 \%$ alkohol yang sinyalir halal, namun dipastikan tidak bisa lolos sertifikasi halal karena tidak sesuai dengan kriteria halal yang seharusnya (halalmui.org, 2020). Hal ini tentu tidak sesuai dengan jargon perusahaan produsen yang mengklaim jika apa yang mereka distribusikan halal dan dapat dikonsumsi siapa saja karena kadar alkohol berjumlah $0 \%$ persen. Pergolakan disonansi kognitif masyarakat Indonesia terhadap pembelian produk dengan sertifikasi logo non halal inilah yang nantinya akan dibahas oleh peneliti.

\section{TINJAUAN LITERATUR}

Teori Disonansi Kognitif

Ilustrasi klasik disonansi pada buku Griffin, 2018 diungkapkan dalam dongeng The Fox and The Grapes oleh Aesop. Dalam cerita ini, ada seekor rubah melihat anggur tinggi dan ingin memakannya. Saat rubah tidak bisa memikirkan cara untuk menjangkau anggur tersebut, dia memutuskan bahwa buah anggur mungkin tidak layak untuk dimakan, dengan alasan buah anggur belum matang atau asam. Contoh ini mengikuti sebuah pola dimana seseorang menginginkan sesuatu, menemukannya namun tidak dapat dicapai, dan mengurangi disonansi dengan cara mengkritiknya (Griffin, 2018).

Teori disonansi kognitif (Festinger, 1957) menyatakan bahwa individu berusaha untuk menjaga konsistensi di antara berbagai kognisi (misalnya, pikiran, perilaku, sikap, nilai, atau keyakinan). Kognisi yang tidak konsisten dapat menghasilkan keadaan yang membuat individu menjadi merasa adanya ketidaksesuaian dalam diri yang akhirnya memotivasi individu untuk mengubah satu atau lebih kognisi untuk mengembalikan konsistensi dengan kognisi lain sehingga individu mendapatkan kesesuaian. Disonansi kognitif adalah salah satu dari sekian banyak teori yang didasarkan pada prinsip konsistensi kognitif yang tumbuh dari teori-teori awal seperti teori keseimbangan (Heider, 1958). Yang unik dari pendekatan Festinger adalah usulan bahwa disonansi kognitif adalah keadaan mental permusuhan yang memotivasi individu untuk mengurangi disonansi tersebut (Miller, 2020)

Menurut Festinger (1957) jika ada sebuah stimulus baru yang diterima oleh individu dan itu berkontradiksi dengan apa yang diyakini, maka akan individu akan melakukan skema yaitu struktur kognitif untuk mengatur informasi yang baru. Hal itu dilakukan agar informasi yang baru dapat dipahami, individu harus bisa menemukan skema yang dapat digunakan untuk menghubungkan stimulus baru dengan pengalaman yang dipahami sebelumnya. (Dainton \& Zelley, 2018). Cara termudah untuk menghilangkan kognisi disonansi ini adalah dengan cara 
mengubah tindakan atau perasaan yang ada pada elemen perilaku, karena perilaku dan perasaan individu seringkali dapat berubah melalui informasi baru yang didapatkan (Festinger, 1957).

Festinger (1957) menjelaskan bahwa derajat disonansi yang dialami individu berkaitan dengan kognisi tertentu yang dilambangkan dengan rasio D / D + C dimana D adalah jumlah kognisi disonan dan $\mathrm{C}$ adalah jumlah kognisi konsonan, masing-masing kognisi diukur oleh kepentingannya. Selain itu, besarnya disonansi yang berkaitan dengan kognisi tertentu tergantung pada jumlah serta signifikansi psikologis dari kognisi disonan (tidak konsisten) dan konsonan (konsisten) dengan kognisi tersebut sehingga "disonansi akan meningkat karena jumlah dan pentingnya kognisi disonan relatif terhadap peningkatan kognisi konsonan (Jones, 2002). Dengan demikian disonansi dapat dikurangi dengan menghilangkan kognisi disonan, memasukkan kognisi konsonan, mengurangi pentingnya kognisi disonan dan menambah pentingnya kognisi disonan

Hal ini tentunya erat berkaitan dengan sikap, keyakinan, nilai, perilaku pemeliharaan atau perubahan yang biasanya mempengaruhi penentuan keputusan (Jones, 2002). Disonansi kognitif sangat terkait dengan perubahan sikap. Seperti yang kita ketahui situasi ini merupakan kebingungan antara dua kognisi yang tidak konsisten satu sama lain. Menurut Schiffman \& Kanuk, 2008 disonansi atau inkonsistensi ini terjadi ketika individu memegang konflik pemikiran tentang suatu keyakinan atau objek. Ketika disonansi kognitif terjadi setelah pembelian, hal itu disebut disonansi pasca pembelian, karena seperti yang sudah disinggung di atas keputusan pembelian seringkali membutuhkan sejumlah kompromi yang nantinya menimbulkan disonansi normal pasca pembelian. Disisi lain, konsumen bisa merasionalisasi keputusan yang tepat, mencari iklan untuk mendukung pilihan atau penampilan mereka untuk mendapatkan jaminan kepuasan.

Pada buku Griffin, Festinger juga menghipotesiskan 3 mekanisme mental yang digunakan orang untuk memastikan tindakan dan sikapnya selaras yaitu, eksposur selektif mencegah disonansi, disonansi pasca keputusan menciptakan kebutuhan untuk kepastian dan justifikasi minimal untuk tindakan menginduksi perubahan sikap

Selain hipotesis tersebut, dalam buku Griffin (2018), Festinger bersama beberapa peneliti lainnya memunculkan 3 keadaan seni revisi yang menjadi sebab akibat dalam disonansi seperti: Konsistensi diri: The Rationalizing animal, tanggung jawab individu atas hasil yang buruk untuk menciptakan new look dan afirmasi diri untuk menghilangkan disonansi

Berdasarkan buku Dainton (2018) Besaran disonansi juga dapat diukur dengan 3 cara yaitu, derajat kepentingan, yang menunjukan seberapa penting disonansi, rasio disonansi, yang menunjukkan seberapa banyak disonansi dan kemampuan merasionalisasi, yang menunjukkan alasan yang di gunakan untuk menjelaskan mengapa inkonsistensi terjadi

Dalam kasus-kasus yang muncul, tergambarlah jika semakin penting masalah dan semakin besar perbedaan antara perilaku kita dan keyakinan itu makan akan semakin besar disonansi yang akan kita rasakan. Festinger juga menganggap kebutuhan untuk menghindari disonansi sama mendasarnya dengan kebutuhan untuk keamanan atau kebutuhan untuk memuaskan rasa lapar, karena ketegangan disonansi memotivasi kita untuk mengubah perilaku dan keyakinan dalam upaya menghindari perasaan tertekan itu (Griffin, 2018).

\section{Perilaku konsumen}

Esterby (2002) menekankan bahwa kepribadian individu dianggap sebagai konsep diri dan persepsi diri yang berpengaruh pada pilihannya untuk membeli suatu barang. Sikap, persepsi, keyakinan, dan evaluasi diri menentukan minat, aktivitas, dan pendapat mereka. Faktor 
terakhir adalah faktor psikologis yaitu persepsi, motivasi belajar, sikap dan keyakinan. Faktor inilah yang dianggap sebagai instrumen konsumen untuk berinteraksi di masyarakat. Dengan mengenali perasaan mereka, meneliti informasi dan mengartikulasikan pemikiran dan pendapat mereka, perusahaan dan pemasar dapat mengambil tindakan untuk memenuhi kebutuhan konsumen yang intens (Oke, Kamolshotiros, Popoola, Ajagbe, Olujobi, 2016)

Kotler (2005) mengemukakan bahwa sangat penting bagi organisasi dan pemasar untuk secara sadar mengenali dan mempertimbangkan perilaku konsumen mereka dan karakteristik yang mempengaruhi perilaku membeli. Lamb (2004) menyatakan bahwa terdapat empat faktor utama yang mempengaruhi perilaku pembelian konsumen. Pertama, faktor budaya seperti budaya dan nilai, subkultur dan kelas sosial konsumen. Budaya menciptakan nilai dasar, persepsi, tuntutan dan perilaku yang dipengaruhi oleh keluarga konsumen, teman dan masyarakat. Faktor-faktor ini lah yang akan mempengaruhi perilaku konsumen pada proses pembelian, karena individu akan menyesuaikan pembelian suatu produk sesuai dengan nilai yang dia percaya (Bose, 2012)

Saat transaksi pembelian selesai, sebagian konsumen merasa keputusan yang ia dapat sangat dipengaruhi oleh intervensi penjual dan memiliki konsistensi kognitif (Bell, 1967, Cummings dan Venkatesan, 1976). Kassarjian dan Cohen (1965) mengatakan bahwa setelah proses pembelian dilakukan, pemikiran individu mulai menilai adanya pro dan kontra dari transaksi pembelian yang dilakukan. Hal ini menimbulkan banyak kognisi yang saling bertentangan di benak pembeli. Suatu aspek positif dari pilihan yang dilupakan dan aspek negatif dari keputusan yang dibuat menciptakan ketegangan yang meningkat dalam pikiran manusia dan membuat pembeli memikirkan kembali keputusan yang dibuat.

Barmola \& Strivastava (2014) mengatakan bahwa salah satu definisi resmi dari perilaku konsumen adalah "Studi tentang individu, kelompok, atau organisasi dan proses yang mereka gunakan untuk memilih, mengamankan, menggunakan, dan membuang produk, layanan, pengalaman, atau ide untuk memenuhi kebutuhan dan dampaknya. proses pada konsumen dan masyarakat. Definisi ini menunjukan bahwa perilaku konsumen ini dapat terjadi secara individu, kelompok bahkan organisasi.

Perilaku konsumen adalah proses pengambilan keputusan dan tindakan orang-orang yang terlibat dalam pembelian dan penggunaan produk. Ini melibatkan pembelian \& aktivitas terkait konsumsi lainnya dari orang-orang yang terlibat dalam proses pertukaran. Perilaku konsumen termotivasi atau bertujuan. Perilaku diarahkan pada tujuan memperoleh produk atau sumber daya lainnya. Ini adalah aktivitas orang-orang yang terlibat dalam penggunaan aktual \& potensial dari item pasar yang berupa produk, layanan, lingkungan ritel atau ide (Berkman, 1992)

Korgaonkar dan Moschis (1982), Proses pengambilan keputusan konsumen melibatkan berbagai langkah dan tergantung pada keterlibatan produk, konsumen melakukan tahapan tahapan tertentu atau mungkin ada tahapan yang terlewat. Semakin banyak ekspektasi sebelum pembelian, semakin banyak pula evaluasi yang menguntungkan pada produk yang melibatkan keterlibatan konsumen yang tinggi (pandey \& Jamwal, 2015).

Semakin baik perusahaan dalam memahami konsumennya, semakin besar kemungkinannya untuk sukses di pasar. Pengetahuan tentang perilaku konsumen akan memberikan bantuan yang sangat besar untuk perencanaan dan penerapan strategi pemasaran. Tanggapan konsumen adalah gambaran utama apakah strategi pemasaran akan berhasil. Dengan demikian, pengetahuan konsumen harus dimasukkan ke dalam setiap aspek rencana pemasaran yang sukses. Dan pengetahuan ini juga membantu memastikan bahwa produk terus menarik pasar intinya (Schiffman \& Kanuk, 2008). Pemasaran yang baik menjaga hubungan yang baik 
dengan pelanggan bahkan setelah pembelian dilakukan. Ini untuk mengurangi kemungkinan disonansi kognitif yang mungkin dialami pelanggan dengan produk. Untuk mengurangi efek negatif dari disonansi kognitif pelanggan, layanan purna jual yang baik dapat disediakan bersama dengan periklanan yang efektif. (Barmola \& Strivastava, 2014).

Halal

Menurut Riaz dan Chaudry (2004) Halal merupakan frasa bahasa Arab untuk sesuatu yang diizinkan menurut hukum Islam. Islam menyatakan bahwa umat Islam hanya mengonsumsi makanan halal. Dalam bahasa Arab, halal berarti diizinkan. Untuk menjadi halal, hewan harus disembelih dengan cara yang dikenal dengan Zabihah atau Zibah, yang melibatkan berkah atas nama Allah. Zabihah mensyaratkan bahwa seekor hewan harus tidak mati sebelum disembelih, seorang Muslim harus melakukan penyembelihan, dan darah yang mengalir dari bangkai harus benar-benar dikeringkan (Halalfoodauthority.com, 2017). Makanan apapun yang berjenis tidak halal itu haram (dilarang).

Selain hal diatas, sambil mengulas kembali apa yang muncul pada latar belakang, menurut penelitian Ahmad, Kadir, Saleludin (2013) ada pula kesadaran halal dimana sikap ini merupakan keadaan sadar seorang muslim yang memiliki ilmu syariah yang baik tentang apa itu halal, mengetahui prosesnya dan mengutamakan yang halal untuk dikonsumsi (Ahmad, Kadir, Saleludin, 2013). Bersebrangan dengan non halal adapula haram yang dalam bahasa Arab berarti dilarang atau melanggar hukum, khususnya bagi muslim. Adapun contoh umum yang paling sering ditemui masyarakat seperti alkohol dan produk babi (Jusmaliani dan Nasution, 2009).

\section{METODE PENELITIAN}

Metode yang kami gunakan dalam penelitian ini adalah studi pustaka. Studi pustaka adalah sebuah kajian yang digunakan untuk memperoleh data-data atau teori dari berbagai sumber seperti buku, jurnal ilmiah, artikel, atau sumber-sumber lain yang ada hubungannya dengan masalah yang akan dibahas dalam penelitian ini. Literatur yang digunakan untuk menjawab permasalahan yang akan diangkat oleh penulis dalam hal ini adalah bagaimana teori disonansi kognitif dapat mempengaruhi perilaku konsumen dalam pembelian produk tanpa logo halal pada masyarakat di Indonesia. Penelitian ini dilakukan dengan pendekatan kualitatif dan menggunakan metode deskriptif analisis, yaitu memberikan gambaran dan pemahaman kepada pembaca tentang teori disonansi kognitif dan perilaku konsumen dalam membeli produk tanpa sertifikasi logo halal pada masyarakat Indonesia. Data yang digunakan oleh penulis dalam penelitian ini adalah data sekunder.

Dalam pengumpulan datanya, pertama, kami mencari literatur yang membahas tentang perkembangan teori disonansi kognitif. Kedua kami mencari literatur yang menghubungkan antara teori disonansi dengan perilaku konsumen dalam pembelian sebuah produk. ketiga kami mencari literatur terkait perilaku konsumen dalam pembelian produk halal. Kemudian kami mencari literatur tentang perilaku konsumen dalam pembelian produk tanpa logo sertifikat halal dalam kasus 5 tahun terakhir. Terakhir, kami melakukan analisis deskriptif yang menjelaskan hubungan antara disonansi kognitif dan perilaku konsumen dalam pembelian produk tanpa sertifikat logo halal pada masyarakat di Indonesia. 


\section{HASIL DAN PEMBAHASAN}

Dalam mendefinisikan konstruksi disonansi kognitif inti kerangka dan konseptualisasinya (Ong, 2017) mencatat bahwa meskipun Penjelasan awal Festinger tentang disonansi tidak secara jelas mengidentifikasi apakah disonansi itu kognitif atau emosional (Sweeney, 2000), konstruksinya dapat dijelaskan dalam istilah emosional meskipun label kognitifnya, sering dirujuk sebagai keadaan motivasi yang tidak menyenangkan (Jones, 2002) atau psikologis ketegangan atau ketidaknyamanan (Carlsmith \& Aronson, 1963; Elliot \& Devine, 1994). Di sisi lain dimensi kognitif terhadap disonansi kognitif juga tersirat, mengingat postulasi Festinger bahwa "disonansi adalah adanya hubungan yang tidak sesuai di antara kognisi", dengan skala tentang "berarti pengetahuan, pendapat, atau keyakinan tentang lingkungan, tentang diri sendiri, atau tentang perilaku seseorang" (Festinger, 1957). Mempertimbangkan hal ini, Ong (2017) menetapkan bahwa konseptualisasi disonansi kognitif (gairah) harus mencakup aspek kognitif dan emosional (Sweeney, 2000) dan menggunakan tipologi Jones (2002) yang diambil terhadap makanan dan konteks nutrisi, masing-masing disebut sebagai perbedaan kognitif terkait makanan (yaitu, ketidakkonsistenan antara dua atau lebih kognisi terkait makanan) dan terkait makanan disonansi (yaitu, ketegangan psikologis atau ketidaknyamanan yang dialami sebagai akibat dari inkonsistensi kognitif terkait makanan).

Jika dikaitkan dengan kasus yang relevan, disonansi kognitif dalam perilaku konsumen masyarakat Indonesia terhadap pembelian produk tanpa logo halal, Indonesia merupakan negara dengan mayoritas penduduknya beragama Islam. Hal ini akan mempengaruhi regulasi yang ada pada negara tersebut, salah satunya adalah regulasi penjualan produk dengan sertifikasi Halal. Pada tahun 2019 pemerintah menerapkan UU Jaminan Produk Halal. Penerapan UU Jaminan Produk Halal ini sudah lama dibentuk oleh pemerintah tapi pada tahun 2019 kebijakan UU Jaminan Produk Halal ini berubah, yang dimana pada awalnya UU ini diterapkan secara sukarela akan tetapi berubah menjadi wajib. UU Jaminan Produk Halal ini menimbulkan pro dan kontra pada masyarakat Indonesia, disatu sisi memberikan kenyamanan pada konsumen dalam membeli sebuah produk dan dengan adanya sertifikasi halal dapat membuat kepercayaan konsumen pada suatu brand menjadi meningkat. Di sisi lain UU Jaminan Produk Halal ini dapat memberatkan UKM karena harus mewajibkan para pemilik UKM untuk memiliki sertifikasi halal, yang dimana proses pembuatan sertifikasi halal ini cukup rumit dan mahal. Tujuan utama dari regulasi ini adalah untuk memberikan kenyamanan kepada dua belah pihak, konsumen maupun penjual. Dengan adanya sertifikasi logo halal ini membuat konsumen tidak menimbulkan disonansi kognisi dalam proses pembeliannya. Seperti salah satu contoh produk minuman tanpa sertifikasi logo halal yang dijual secara bebas di minimarket, Bintang Zero Grape 0.0\% maupun Bintang Radler Lime $0.0 \%$ yang rilis pada tahun 2016. PT Multi Bintang Indonesia Tbk yang bergerak di bidang produsen bir di Indonesia ini melakukan inovasi pada produknya, yaitu dengan membuat produk tanpa alkohol. PT Multi Bintang Indonesia mengatakan bahwa proses pembuatan bintang zero $0.0 \%$ dan Bintang Radler 0.0\% ini dibuat pada pabrik yang terpisah dengan pembuatan bir beralkohol dan menggunakan bahan-bahan yang bersertifikasi halal dan lolos pengawasan dari BPOM serta tanpa adanya proses fermentasi dalam pembuatannya (pressrelease.kontan.co.id, 2020). Pernyataan dari PT Multi Bintang Indonesia tetap memberikan keraguan pada proses pembelian konsumen di Indonesia, terlebih masyarakat Indonesia mayoritas beragama muslim dan dari Lembaga Halal Indonesia pun tidak memberikan sertifikasi logo halal pada produk tersebut.

Berdasarkan pemaparan diatas adanya disonansi kognisi pada konsumen dalam proses pembelian ini dikarenakan adanya ketidakyakinan pada brand tersebut. PT Multi Bintang 
Indonesia yang merupakan produsen bir di Indonesia membuat konsumen berpikir bahwa segala produknya mempunyai unsur alkohol di dalamnya, dan ketika ada produk bintang zero 0.0\% maupun bintang radler $0.0 \%$ tidak langsung membuat beberapa calon konsumen terutama masyarakat muslim memutuskan untuk membeli produk tersebut. Disonansi disini adalah konsep psikologis yang memiliki pengaruh yang besar pada cara konsumen merencanakan pembelian mereka dan efek pembelian. Di era pemasaran, dimana konsumen diberikan kemudahan dengan banyaknya pilihan mengenai produk yang akan dibeli, sulit untuk menghindari situasi kebingungan yang berujung pada disonansi diantara konsumen. Namun, konsumen melakukan upaya yang berbeda untuk mengurangi pandangan yang bertentangan yang muncul di benak mereka. (Hasan, 2012).

Selain itu, ada beberapa faktor yang dapat menciptakan disonansi kognitif. Beberapa di antaranya seperti nilai, kepercayaan, sikap, adat istiadat, filosofi politik, nilai agama, reaksi emosional, norma, budaya, status sosial, pengaruh kelompok sebaya dll. Individu yang hidup dalam budaya tertentu mungkin memiliki keyakinan kuat bahwa dia harus membeli produk yang harus diterima oleh budaya tersebut. Dalam membeli suatu produk, orang yang hidup dalam suatu budaya dapat menimbulkan konflik dalam diri seperti adanya pemikiran bahwa barang tersebut sudah sesuai dengan budaya yang dimiliki sehingga situasi ini menciptakan disonansi kognitif (Bose, 2012). Selain itu individu yang memiliki nilai, kepercayaan dan adat istiadat yang berbeda dapat menimbulkan disonansi dalam hal pembelian produk. Nilai religius adalah salah satu faktor terpenting yang bertanggung jawab untuk menghasilkan disonansi kognitif. Orang yang berbeda agama membeli barang berdasarkan keyakinan agama mereka. Beberapa barang sangat dilarang oleh beberapa agama dan ketika orang membelinya, itu menciptakan disonansi. Selain nilai politik tersebut, reaksi emosional, status sosial juga mempengaruhi keputusan pembelian sehingga menimbulkan disonansi kognitif (Bhasin, 2010). Melihat dari kasus yang sebelumnya sudah dibahas, pembelian suatu produk tanpa adanya sertifikasi logo halal menimbulkan disonansi kognisi pada konsumen dalam proses pembelian, hal ini dikarenakan adanya faktor budaya maupun nilai religi yang dianut oleh individu tersebut. Jika individu memiliki nilai religius yang dimiliki dan dalam konteks ini adalah beragama Islam, maka individu itu akan menimbulkan disonansi kognisi sebagai konsumen dalam proses pembelian suatu produk dikarenakan hal tersebut berbeda dengan apa yang dipahami sebelumnya yang dimana suatu produk akan aman digunakan jika sudah ada sertifikasi logo halal.

Disonansi lainnya juga sering dihubungkan dengan kendala saat seseorang hendak membuat keputusan. Hal ini berkaitan dengan adanya batasan waktu yang membuat seseorang harus menentukan keputusan secara spontan dan tidak terencana sebelumnya (Rook dan Fisher, 1995). Akibatnya muncul sikap impulsif pada konsumen ketika hendak membeli sesuatu. Namun, jika proses pembelian direncanakan dengan matang maka tingkat disonansi yang dirasakan konsumen lebih sedikit. Ini karena semakin banyak waktu yang dihabiskan konsumen dalam membuat keputusan untuk membeli, akan semakin berkurang penyesalan yang nantinya muncul. Begitu pula dengan fenomena perilaku konsumen masyarakat Indonesia yang penasaran terhadap pembelian produk tanpa logo halal.

Lainnya, disonansi kognitif konsumen sering dikaitkan dengan ketidakpuasan konsumen. Restoran dan operator makanan cepat saji berisiko kehilangan pembelian berulang jika konsumen mengalami disonansi kognitif. Selain itu, pelanggan yang tidak puas biasanya terlibat dalam promosi mulut ke mulut yang negatif, sehingga dapat menimbulkan konsekuensi negatif bagi organisasi layanan apapun, seperti kehilangan pelanggan dan merusak reputasi. Para peneliti 
mungkin kurang memperhatikan disonansi kognitif dalam beberapa tahun terakhir karena peningkatan minat dalam kepuasan sebagai konstruksi evaluatif pasca-pembelian (Wilkins, et al, 2016). Akan tetapi, Koenig-Lewis dan Palmer (2008) menyatakan bahwa emosional seseorang dapat menjadi prediktor yang lebih baik untuk perilaku pembelian berulang daripada ukuran kepuasan. Dengan kata lain, ketidakpuasan konsumen akibat disonansi kognitif dapat menyebabkan pengaruh yang lebih kuat daripada niat membeli kembali dibandingkan kepuasan konsumen. Dalam penelitian ini, ada kemungkinan konsumen mengalami disonansi kognitif bukan karena mereka menyesal makan makanan halal tetapi karena mereka merasa kecewa atau tertipu oleh organisasi yang berusaha sembunyikan fakta bahwa mereka menyajikan halal. Sehingga ini menjadi alasan lain untuk memasukkan disonansi kognitif dalam konsep jurnal kami.

Tambahan, berdasarkan jurnal Cognitive Dissonance Affecting Consumer Buying Decision Making: A study Based on Khulna Metropolitan Area (Tarun, 2012). Disonansi kognitif menjadi faktor penting dalam mempengaruhi sikap pelanggan. Ini lagi-lagi adalah situasi dua kognisi yang tidak konsisten satu sama lain. Setelah disonansi terjadi konsumen pasti akan membuat keseimabngan dalam kognisi dengan mencoba mengurangi disonansi. Dengan perubahan sikap inilah, konsumen tersebut berharap dapat mendapatkan konsistensi kognitif. Semua orang yang mengalami proses ini tentunya mengalami disonansi internal atau disonansi intra sikap karena konflik yang terjadi antara komponen afektif juga kognitif atas sebuah sikap. Contoh jika sekelompok konsumen percaya bahwa merek atau produk tertentu tidak baik, maka distributor dari merek tersebut akan mengembangkan iklan yang informatif dan persuasif untuk menampilkan merek kepada pelanggan, hal ini dilakukan untuk membawa perubahan pada sikap mereka (Festinger, 1957). Itulah yang dilakukan distributor makanan dan minuman yang belum mendapat sertifikasi logo halal di Indonesia.

\section{KESIMPULAN}

Dari penelitian diatas, pendekatan disonansi kognitif masih bisa relevan untuk digunakan dalam membahas perilaku konsumen dalam proses pembelian suatu produk. Dalam penelitian selanjutnya untuk membahas lebih dalam lagi tentang disonansi kognitif yang ada pada perilaku konsumen perlu adanya penggunaan teori lain selain teori disonansi kognitif, sehingga hasil yang didapat bisa lebih mendalam tentang memahami disonansi yang ada pada konsumen dalam proses pembelian suatu produk. Dengan memahami disonansi yang ada pada konsumen, penjual akan dapat memahami bagaimana pemasaran suatu produk dengan baik sehingga dapat mereduksi disonansi yang ada pada konsumen.

Adanya nilai dan budaya tertentu yang dianut oleh individu dapat mengubah sikap perilaku konsumen. Nilai dan budaya yang dianut dapat menimbulkan disonansi dalam membeli suatu produk. individu biasanya akan membeli barang sesuai dengan nilai dan budaya yang mereka percaya. Banyak upaya dapat dilakukan untuk meningkatkan kesadaran produk masyarakat Indonesia terhadap label halal dan non halal. Perspektif masyarakat terhadap sertifikasi juga sangat berpengaruh terhadap respon masyarakat umum dalam mencerna keamanan konsumsi berlabel tertentu, seperti sikap, keyakinan, media massa, hingga orang sekitar. LPPOM MUI sebagai lembaga penjamin memainkan peranan penting dalam membentuk sikap masyarakat. Dari penelitian diatas diketahui bahwa teori disonansi kognitif dalam menentukan perilaku pembelian produk tanpa logo halal masih sangat bisa dikaitkan pada tahun milenial ini. 


\section{DAFTAR PUSTAKA}

Ahmad, M., Kadir, S., and Saleluddin, N. (2013). Perception and Behavior's of Muslims and Non-Muslims Towards Halal Products. Journal of Social and Development Sciences.

Ahmad, N. A. B., Tunku Abaidah, T. N. Bin, \& Abu Yahya, M. H. Bin. (2013). A Study on Halal Food Awareness Among Muslim Customers in Klang Valley. 4Th International Conference on Business and Economic Research (4TH ICBER 2013) PROCEEDING. Bandung

Awan, H. M., Siddiquei, A. N., \& Haider, Z. (2015). Factors Affecting Halal purchase Intention - Evidence from Pakistan's Halal Food Sector. Management Research Review, 38(6), 640-660. https://doi.org/10.1108/MRR-01-2014-0022

Aronson, E. 1969, „The theory of cognitive dissonance: A current perspective", Advances in Experimental Social Psychology, vol. 4, ed. L. Berkowitz, Academic Press, New York, pp. $1-34$

Bose, Tarun Kanti. (2012). Cognitive Dissonance Affecting Consumer Buying Decision Making: A Study Based on Khulna Metropolitan Area. Journal of Management Research

K.C, Barmola., S.K, Strivastava. (2010). The Role Of Consumer Behaviour In Present Marketing Management Scenario. India: Gurukul Kangri University

Dainton, Marianne., Zelley, Elaine. (2019). Applying Communication Theory for Professional Life. 4th ed. Thousand Oaks: SAGE Publications, Inc

Standard, Dinar., Reuters, Thomson. (2018). State of the Global Islamic Economy Report 2018/19. In Dubai International Financial Centre.

Leon, Festinger. (1957), a theory of Cognitive Dissonance, Stanford University Press, Stanford, CA

Fithriana, Arin \& Annissa, Jeanne. (2018) Codex Alimentarius: Indonesia's Halal Food Challenges as Culture Identity in International Trade. DOI: 10.2991/icocspa-17.2018.27

Ghadikolaei, F. S. (2016). The Effect of Halal Signs and Symptoms on Consumers 'Purchase Intention in Muslim and Non-Muslim Countries- A Review. International Journal of Business and Management Invention, 5(7), 44-49.

Griffin,. Ledbetter,. Sparks. (2018). A First Look at Communication Theory. McGraw Hill. New York

Hasan, Uzma. (2012) Cognitive Dissonance and Its Impact On Consumer Buying Behaviour. DOI: $10.9790 / 487 \mathrm{X}-0140712$

Jones, Harmon E. (2007). Cognitive dissonance theory after 50 years of development. Zeitschrift Fur Sozialpsychologie. https://doi.org/10.1024/0044-3514.38.1.7

Heider, F. (1958c). The psychology of interpersonal relations. New York: Wiley.

Jusmaliani., Nasution, Hanny Nofrida. (2009). Religiosity Aspect in Consumer Behaviour: Determinants of Halal Meat Consumption. ASEAN Journal Marketing.

Kassarjian,. Cohen, Joel B. (1965), “Cognitive Dissonance and Consumer Behavior”, California Management Review, Vol. 8, No. 1, pp. 55-64.

Khaleka, Abdul Aiedah. Young consumers' attitude towards halal food outlets and JAKIM's halal certification in Malaysia. Taylors University, Malaysia 
Lamb, C.W., Hair, J.F., McDaniel, C. (2004), Marketing. 7th ed. Oxford: Oxford University Press.

Miller. (2020). Cognitive Dissonance Theory (Festinger).

N.A.B., Ahmad. et al (2013) A Study on Halal Food Awareness Among Muslim Customers in Klang Valley. 4Th International Conference on Business and Economic Research (4TH ICBER 2013) PROCEEDING, 1073-1087. Bandung.

Oke, Adunola., Kamolshotiros, Parinda., Popoola, Oluwamayowa Yewande., Ajagbe, Musibau Akintude., dan Olujobi, Olusola Joshua. (2016). Consumer Behavior towards Decision Making and Loyalty to Particular Brands. International Review of Management and Marketing.

A.C, Pandey,. M, Jamwal. (2016). Realizing the Impact of Cognitive Dissonance in Predicting Consumer Behavior. Journal of Social Sciences, 12(1), 36-41. https://doi.org/10.3844/jssp.2016.36.41

M.N. Riaz,. M.M, Chaudry. (2004), Halal Food Production, CRC Press, LCC, Boca Raton, FL.

Dennis, Rook., Robert, Fisher J. (1995), “Trait and Normative Aspects of Impulsive Buying Behavior”, Journal of Consumer Research, Vol. 22, No. 3, pp. 305-313.

Schiffman, dan Kanuk. (2008). Perilaku konsumen. Edisi 7. Jakarta.

Soon, Mei Jan. (2017) Halal integrity in the food supply chain. DOI: 10.1108/BFJ-04-20160150

Wilkinsa, Stephen., Butt, Muhammad Mohsin., Shams, Farshid., Perez, Andrea. (2017). Product standardization in the foodservice industry: postpurchase attitudes and repurchase intentions of non-Muslims after consuming halal food. https://doi.org/10.1080/0965254X.2017.1384749

\section{Internet}

MUI, LPPOM. (08 Oktober 2020). Klarifikasi Hoax, MCD, KFC, Domino's, dan Pizza Hut. https://www.halalmui.org/mui14/main/detail/klarifikasi-hoax-mcd-kfc-dominos-dan-pizzahut

MTH. (22 Maret 2019). [DISINFORMASI] Sertifikat Halal McDonald's, KFC, DOMINOS \& PIZZA Hut Dicabut. https://www.kominfo.go.id/content/detail/17393/disinformasisertifikat-halal-mcdonalds-kfc-dominos-pizza-hut dicabut/0/laporan_isu_hoaks /

LPPOM MUI. (2018). Data Sertifikasi Halal LPPOM MUI Periode 2011-2018. www.halalmui.org/mui14/index.php/main/go_to_section/59/1368/page/1\%0A

Halalfoodauthority.com. (16 February 2017). Definition of halal. https://www.halalfoodauthority.com/definition-of-halal

Hukmana, Siti Yona. (2019). Penerapan UU Jaminan Produk Halal Tantangan bagi MASYARAKAT HTTPS://WWW.MEDCOM.ID/EKONOMI/MIKRO/RB15YOAB-PENERAPAN-UUJAMINAN-PRODUK-HALAL-TANTANGAN-BAGI-MASYARAKAT

KONTAN. (2020). BINTANG RADLER 0.0\% LUNCURKAN VARIAN BARU YANG MENYEGARKAN. HTTPS://PRESSRELEASE.KONTAN.CO.ID/RELEASE/BINTANG-RADLER-00-LUNCURKAN-VARIANBARU-YANG-MENYEGARKAN 